University of Montana

ScholarWorks at University of Montana

2010

\title{
Healthcare Reform: A Prescription for the 2010 Republican Landslide?
}

Robert P. Saldin

University of Montana - Missoula, robert.saldin@umontana.edu

Follow this and additional works at: https://scholarworks.umt.edu/polisci_pubs

Part of the Political Science Commons

Let us know how access to this document benefits you.

Recommended Citation

Saldin, Robert P., "Healthcare Reform: A Prescription for the 2010 Republican Landslide?" (2010). Political Science Faculty Publications. 4.

https://scholarworks.umt.edu/polisci_pubs/4

This Article is brought to you for free and open access by the Political Science at ScholarWorks at University of Montana. It has been accepted for inclusion in Political Science Faculty Publications by an authorized administrator of ScholarWorks at University of Montana. For more information, please contact scholarworks@mso.umt.edu. 


\title{
The Forum
}

Volume 8, Issue 4

2010

Article 10

MIDTERM ELECTIONS OF 2010

\section{Healthcare Reform: A Prescription for the 2010 Republican Landslide?}

\author{
Robert P. Saldin, Harvard University and University of \\ Montana
}

\section{Recommended Citation:}

Saldin, Robert P. (2010) "Healthcare Reform: A Prescription for the 2010 Republican Landslide?," The Forum: Vol. 8: Iss. 4, Article 10.

DOI: $10.2202 / 1540-8884.1404$

Available at: http://www.bepress.com/forum/vol8/iss4/art10

C2011 Berkeley Electronic Press. All rights reserved. 


\title{
Healthcare Reform: A Prescription for the 2010 Republican Landslide?
}

\author{
Robert P. Saldin
}

\begin{abstract}
Less than two years ago, Barack Obama was sworn in as president amidst proclamations of a partisan realignment. But in this fall's midterms, scores of his fellow Democrats lost their jobs. The best evidence suggests that Obama's signature accomplishment — passage of a healthcare reform bill that had long eluded progressives - played a key role in the historic defeat. It also highlighted the delicacy of partisan regimes, particularly those prematurely designated as realignments by academic or popular observers.
\end{abstract}

KEYWORDS: election, healthcare, parties, realignment, Barack Obama

Author Notes: Robert P. Saldin is a Robert Wood Johnson Scholar in Health Policy Research at Harvard University and an assistant professor of political science at the University of Montana. He is the author of War, the American State, and Politics since 1898 (Cambridge University Press). His scholarly articles have appeared in The Journal of Politics, Political Research Quarterly, The Journal of Policy History, and elsewhere. 
Whatever happened to Barack Obama's realignment? When the Illinois Senator took the Oath of Office less than two years ago, journalists, pundits, and Democrats everywhere eagerly proclaimed his decisive victory to be the dawning of new political era. It was widely thought that the 2008 contest was primed to join that elite Mount Rushmore-class of presidential elections known to political scientists-as well as journalists, politicos, and even casual observers-as "realignments."

But now Obama's 2008 victory appears more likely to join the significantly less esteemed class of elections yielding one-term presidents. Of course, much can change in two years, and the weak slate of potential 2012 Republican nominees is sufficient to offer even the most depressed Democrats a new infusion of hope for their president's reelection. Yet regardless of what happens in two years, talk of an enduring, Obama-spurred realignment appears to have passed.

The fundamental problem with realignment theory is that it distorts American political history by forcing it into awkward contortions to conform to the theory's ambitions. But the theory offers an appealing framework for compartmentalizing American political history, so mainstream journalism has adopted the term, often in its more strident conception. Now our presidentsObama more than most-are held to unrealistic and historically dubious standards.

In tracing the hard-fought passage of the Patient Protection and Affordable Care Act, colloquially known as Obamacare, and its influence on the 2010 midterm election, it becomes clear that even achieving historic legislative accomplishments is insufficient to satisfy a political class infused with realignment mythology. That Democrats paid a steep price in November for their long-coveted law should not be a surprise because healthcare reform has always been polarizing.

Certainly, some of the blame for the widespread disappointment afflicting the nation as a whole and Democrats in particular lies squarely with Obama. As effective as his 2008 campaign was for getting him to 1600 Pennsylvania Avenue, it has been a liability since he moved in. Discontent with President George W. Bush and his policies formed the Obama campaign's foundation, while emotional, forward-looking platitudes like "hope" and "change," combined with an oddly nostalgic collective pining for the good fights of the "60s, filled in the gaps and allowed voters to see the dashing candidate as a liberal champion or a tempered and moderate statesman, depending on their persuasion. And the rock-star idolatry that fueled Obama's campaign called for an encore that no president could deliver. But whatever responsibility lies with Obama, the realignment paradigm has distorted American political history and, in so doing, has also established unrealistic expectations for our presidents. 


\section{Realignment Theory in the Ivory Tower and Beyond}

No concept from the academic discipline of political science has received more play outside the ivory tower than realignment. Every four years, cable news programs and op-ed pages hash out the potential for the coming election to usher in a new era of American politics. Predictably, conventional wisdom in late 2008 held that we were witnessing one of these rare surrogate revolutions (e.g., Davis 2008; Judis 2008).

Yet few remembered that only four years earlier we had been subjected to pronouncements hailing the dawning of a new Republican era led by President Bush and his in-house realignment theorist Karl Rove. Modeled after the GOP's 1896 realignment, Rove saw Bush as a latter-day William McKinley and himself as the reincarnation of Mark Hanna (Green 2007). Yet the purported Republican realignment imploded within months and was quickly forgotten. Realignment chatter then re-emerged following the 2006 midterms-in which Democrats captured both houses of Congress - when Obama surfaced as a viable presidential candidate.

This preoccupation with realignment grew out of a rich literature in political science that developed over several decades. The consummate political scientist, V.O. Key, Jr., (1955) coined the term in the 1950s, and the theory evolved from there (most especially via Schattschneider 1960, Burnham 1970, and Sundquist 1983). In a nutshell, realignment theory suggests that every so often an important election comes along that upends partisan politics for an extended period of time. The once-dominant party is thrown to the curb to languish in minority status, while the formerly marginalized party (or a new party) assumes control. Naturally, the new governing party has its own ideas about public policy and goes about implementing them, thus taking the country in a different direction. Eventually the era runs its course and a new realignment ushers in another era.

According to realignment theorists, only five elections clearly meet this standard. The first occurred in 1800 when Thomas Jefferson, with his populiststyle of democracy, led the Democratic-Republicans to Washington after dispatching Federalist John Adams. The next realignment came in 1828 and saw "The Democrat," Andrew Jackson, defeat John Quincy Adams and reinvigorate the two-party system. Abraham Lincoln and the newly formed Republican Party emerged on the scene in 1860 to initiate the third realignment. Next, William McKinley swept the GOP into power in 1896. And finally, in 1932, Franklin Roosevelt's New Deal Democrats took the reins in the nation's capital.

The two pairs of back-to-back realignments favoring the same party constitute an immediate oddity for realignment theory. How could the realignment of Jefferson, the founding father of the Democratic Party, be replaced 
by that of another Democrat? In this first case, realignment theorists plausibly claim that because the Jeffersonian Era's two-party system (DemocraticRepublicans versus Federalists) fizzled into the single-party "Era of Good Feelings," the reemergence of a vibrant two-party system in 1828 counts as a realignment. That rationale seems plausible enough. But then the problem crops up again in the next pair of realignments. And this time there is no good explanation. How the 1860 Republican realignment came to be replaced by another Republican realignment in 1896 remains an unsolved mystery in the realignment cannon.

A more significant problem emerged in the late 1960s at the theory's most exciting moment. New Dealers were still running the show in what was considered the on-going, natural, 1932-based Democratic era (albeit with Republican Dwight Eisenhower's two terms awkwardly sandwiched in the middle). The excitement owed to the discovery of a new wrinkle by some of the theory's most committed adherents. Looking back on American political history, they realized that critical elections did not occur randomly or merely when a compelling leader happened upon the scene. Rather, they occurred according to a predictable generational cycle, or every 30-38 years.

This scientific discovery meant that the 1960s were an exciting time for political scientists, because a transformational moment was clearly imminent. But then nothing happened. Lyndon Johnson's 1964 landslide victory appeared to be a possibility, but-in addition to Johnson's New Deal credentials and focus on finishing what Roosevelt started - the Great Society crumbled in Vietnam, of all places, bringing a Republican to office only four years later. And Richard Nixon's 1968 and 1972 victories failed to measure up to realignment standards. Political scientists were left waiting with Linus for the Great Pumpkin. Realignment theory has never quite regained its old confidence.

It is worth noting that the concept of realignment was a political sciencespecific move. Political historians and the other social scientists working on American politics never adopted the terminology and have frequently emphasized the importance of other periods, such as the Progressive Era. Why, then, did political science fall so hard for realignment theory? At least four factors seem to have been at work:

- First, even if one is not convinced of realignment theory's accuracy, plenty of evidence supported aspects of its periodization scheme. Most importantly, the five elections it identified could all reasonably be deemed more important than average.

- Second, realignment theory satisfied the social science pursuit of categorization. Historians, by contrast, tend to be less concerned with simplifying, categorizing, and ordering. 
- Third, political scientists may have overemphasized elections because they are rich in easily accessible social science data.

- And finally, given the theory's origins in the 1950s and 1960s, its practitioners may have been overly preoccupied with an enthusiasm for Franklin Roosevelt's New Deal. In many ways, it is that 1932-based party system that is the classic example of realignment. It may well have induced political scientists who came of age during that period to begin working backward in search of previous such moments in American political history.

Though dissident political scientists (Shafer 1991, Mayhew 2002) have been questioning realignment's viability for some time, these critiques never made the transition into popular discourse. That is unfortunate, because the media seems to have been enchanted with the hard version of realignment in which electoral transformations can be expected on a generational cycle and in which the nation is pleasantly unified behind a common agenda. Anything short of Lincolnian statesmanship or FDR's stoic resolve is seen as failure. However, it seems unlikely that a time-warped Lincoln or Roosevelt would be able to live up to today's retrospective Lincolnian or Rooseveltian standards.

That puts today's presidents in a tough spot. With the benefit of hindsight, it is clear that Bush's failure to produce a realignment was over-determined. The same may well be true of Obama. But it is also true that we are not likely to see a realignment like those we associate with Lincoln, McKinley, or FDR, because those realignments were not nearly as seamless as the nostalgic realignment narrative suggests. We forget that Lincoln was poised for defeat in 1864 before Atlanta serendipitously fell to Union forces and changed popular perceptions of the Civil War. Likewise, the Republicans' thirty-six year "System of 1896" awkwardly included ten years of progressive Democratic control on Capitol Hill and in the White House (Saldin 2010). And Franklin Roosevelt failed to get a number of his key legislative priorities passed into law and probably would have been defeated in 1940 had it not been for the specter of World War II.

While it is natural to seek periodization schemes like that offered by realignment theory, deterministic claims that ignore political context need to be avoided. The durability of realignment theory's partisan regimes can also be easily exaggerated. In reality, partisan regimes tend to be delicate and subject to reversal. America's two-party system has historically created a relatively even playing field in which the "out" party—even after landslide defeats—can fairly easily adjust to new circumstances and become competitive again. Additionally complicating the durability of party systems are random and unforeseen events that can quickly alter the political landscape.

Most importantly here, policy achievements and failures can also upset balances established during campaigns. In choosing to pursue a given policy 
agenda, other policy areas are marginalized. These points of emphasis raise the salience of some policies while demoting that of others. And these decisions, in turn, have political and electoral implications. These and other political realities are prime reasons why periodization is difficult and why realignment theoryparticularly in its most brash version-obscures as much as it illuminates in American political history. And those distortions do not do any favors for our contemporary presidents.

\section{Obamacare Fallout}

Whatever one thinks of the Patient Protection and Affordable Care Act, it is rightly seen as an historic legislative accomplishment. During the debate over the bill, some Democrats and liberals were surprised that the American public was already skeptical of their proposals for reforming healthcare. That is surprising. The history of health policy reform efforts is not pretty. Obama followed a wellworn presidential path in his attempt to transform America's health care system. For most of his predecessors, it was a treacherous road that ended in disappointment.

The obvious and primary reason for these difficulties—but an aspect of this most recent incarnation of the debate that is too frequently overlooked-is that healthcare reform is a high-stakes and controversial policy area that raises challenging questions for the American polity. Among other points of tension, there are perceived implications for two of America's fundamental ideals: liberty and equality. Passage of Obamacare required a political perfect storm, and even then it almost fell apart. It should not be surprising that an historic change to a high profile, divisive, and emotionally charged policy area would have electoral implications.

\section{A Short History of Presidential Health Care Initiatives}

In previous work, I have highlighted the way in which international crises in general, and wars in particular, have shaped elections and upset the fragile realignment framework (Saldin 2008; 2010; 2011). Of course, as the 2010 midterms aptly demonstrate, wars do not always dominate campaigns and elections, even when the United States is actively involved in them. The ongoing conflicts in Iraq and Afghanistan, despite having influenced three prior U.S. elections, were non-factors this time. For the 2010 midterms, healthcare reform is likely to be remembered as having played a critical role in the political fortunes of the two parties. Further, like wars and other issues in previous contests, healthcare reform's role in this election cycle highlights the delicacy of partisan regimes- 
particularly those that have been prematurely tagged as realignments, be it by academic or popular observers.

To set the scene in which the Obamacare debate played out and in which the 2010 elections were held, it is helpful to understand, at the very least, the basic contours of health policy history. Until relatively recently, it was not pleasant to find oneself in a hospital, because it meant you were poor and about to die. Those with even modest means paid doctors affordable fees for home visits (Starr 1982). The first calls for health insurance began in the Progressive Era, though these overtures were as much attuned to disability compensation for illness-induced work absences as they were for the cost of the healthcare itself, which remained relatively low (Berkowitz 2010). As a result of these early concerns, some private employers and states began offering disability insurance that complimented national programs already in place.

Over time and as costs increased, though, liberal reformers came to embrace the idea of nationalized, government-sponsored health insurance to cover healthcare costs. The first major episode in this push came during the debate over Social Security in 1935. There was a potential window of opportunity for universal health insurance to make its way into the bill, but it was ultimately left out of the version Franklin Roosevelt signed (Hirshfield 1970; Blumenthal and Morone 2009, 31-56). In this post-1935 vacuum, in which insurance was increasingly seen as necessary, the private insurance industry, bolstered by favorable federal incentives and investments, developed and filled the gap.

The progressive dream of universal coverage provided by the government, however, never died. Amidst rising healthcare costs, President Harry Truman pushed for a national health-insurance plan but was forced to abandon his efforts when the Korean War broke out (Blumenthal and Morone 2009, 67-98). President John Kennedy also made a major push for reform, but he was thwarted as well. Progressives finally gained some traction under Lyndon Johnson in 1965 with the enactment of Medicare, a governmental program to cover the elderly (Marmor 1973; Oberlander 2003). Understanding that any proposal for universal coverage would be dead on arrival in Congress, Johnson was content with this incremental step. Though it failed to provide universal, government-sponsored health care, progressives saw Medicare as a building block toward that ultimate goal.

The next step in that direction occurred in 1972 when Medicaid was enacted to extend coverage to the poor and disabled (Olson 2010). But in an era of rising costs and tight budgets, progress toward universal coverage again stalled. President Jimmy Carter's efforts to enact universal coverage failed. And, most recently, President Bill Clinton's plans met with disaster (Hacker 1997). During this multi-decade stretch, numerous other proposals for universal healthcare were drawn up in Congress but failed to become law. Small, incremental steps continued to be made, most recently with the George W. Bush-sponsored 
expansion of Medicare to provide a prescription drug entitlement. But these increases in the governmental role in American healthcare fell well short of the long-coveted liberal vision of universal coverage.

Some proponents of Obama-style healthcare reform apparently failed to understand this troubled policy legacy. As Edward D. Berkowitz (2010) has argued, academics have too frequently succumbed to a "simplistic and ideologically predetermined framework" in which universal, national health insurance is assumed to be universally popular, only to be thwarted by nefarious forces-such as the American Medical Association and insurance company lobbyists-eager to spread death and disease from sea to shining sea. Those Obamacare advocates taken unaware by the hostility to the new law would seem to also fit Berkowitz's mold. Certainly, there is much truth in assertions that organized interests played an important role in squelching various iterations of health care reform. Yet the same is true in other policy areas, as well. One need only recall the incident in which Rod Page, Secretary of Education under President George W. Bush, referred to a leading teachers union as a "terrorist organization" shortly after $9 / 11$ in order to realize that organized interests have frequently frustrated reform efforts emanating from points across the partisan and ideological spectrum. Yet, sanctimoniously focusing solely on sinister forces opposing healthcare reform-ostensibly because they relish pain and sufferingobscures the more basic and fundamental difficulty facing healthcare reformers: the American political system has multiple veto points, and many citizens, as well as organized interests, prefer the status-quo to new policies with uncertain implications.

These factors that long repelled progressive efforts to reform American health care make the Affordable Care Act's passage all the more remarkable. Though it falls short of the liberal dream of universal coverage, the program represents an enormous step in that direction. Elections have consequences, and the 2006 and 2008 cycles put Democrats in a position to pass Obamacare with or without the American public's endorsement. Such is governing in a representative democracy. But governing decisions by elected politicians also have consequences.

\section{Health Care Reform and the 2010 Midterms}

The 2010 midterms were an historic defeat for the ruling Democrats. The GOP gained 63 House seats and control of that chamber, six Senate seats, six governorships, plus some 700 state legislative seats and control of 22 statehouse chambers. Certainly, the sputtering economy played a key role, as did the various long-term factors emphasized by behavioral political scientists (e.g., Berelson et al. 1954; Campbell et al. 1960; Fiorina 1981; Jacobson 1997). But this year's 
sweeping Republican triumph will be appropriately remembered as, at least partially, an outgrowth of healthcare reform.

The debate over the extent to which the healthcare bill influenced the election began weeks before citizens even went to the polls (Cost 2010) and peaked in the days following the GOP landslide (e.g., Galston 2010; Bernstein 2010). And while it is clear that the Democrats' defeat was over-determined, the best evidence suggests that the Affordable Care Act played a leading role in the Republican gains.

There were plenty of warning signs that this was going to be a tough election for Democrats. Polling on healthcare reform, the generic congressional ballot, and President Obama's job approval all pointed to trouble, and the timing suggests a link between the public's perceptions of Democrats and the health bill. Dozens of polls demonstrate that healthcare reform as designed by Democrats has been consistently and steadily unpopular with the American public (Real Clear Politics 2010a). It enjoyed a brief moment of popular support beginning in April of 2009, when polling began, and lasting through June of that year. But since then, polls have routinely shown opposition to Democratic plans. The November edition of the widely respected Kaiser Health Tracking Poll offers a snapshot of how the American public perceived the Affordable Care Act at the time of the election (Kaiser Health Tracking Poll 2010). It found that $49 \%$ of Americans wanted to repeal part or all of the law, while only $40 \%$ wanted to keep it as-is or expand it.

Considerations of timing suggest a connection between public opinion toward the health bill and that expressed toward congressional Democrats and President Obama. Perhaps the best overall indication of public opinion concerning the two parties is measured by the generic congressional ballot (Real Clear Politics 2010b; Cost 2010). Democrats held a solid advantage until the summer of 2009, when the gap narrowed. On September 2, after a summer of town hall meetings featuring defensive Democrats trying to explain the healthcare bill to their frequently outraged constituents, Republicans briefly pulled ahead. With the end of the August recess, Democrats eagerly retreated back to Washington and regained their advantage in the generic poll, topping out with a $5.5 \%$ lead on October 20, 2009.

Yet when debates over the Affordable Care Act began on the House floor the following month, Republicans pulled even. By the time the President signed the bill into law, they were on top. Critically, the GOP's surges in the generic ballot occurred when healthcare was front and center, but also when the economy appeared to be improving - a factor that presumably would work in the ruling Democrats' favor.

President Obama's approval ratings also appear to have moved in sync with the relative prominence of the healthcare debate (Real Clear Politics 2010c). 
Obama first dipped below 50\% approval in November of 2009, right when the healthcare debate heated up on Capitol Hill. And his numbers took an especially strong hit with independents. On March 18, three day before House passage and five days before the President's signing ceremony, more Americans disapproved of Obama's job performance than approved for the first time during his presidency. In short and although it is impossible to draw a direct causal link, timing suggests a connection between healthcare reform and the Democrats' polling woes. Obama and the Democrats were at their low points in public opinion when the healthcare debate was highly visible.

Post-election surveys also suggest that Republicans benefited mightily from the fallout over the Affordable Care Act. Post-election polling, too, has its limitations. Research has raised doubts about peoples' ability to accurately explain their voting behavior in the way that exit pollsters ask them to do (Bernstein 2010; Rahn, et al. 1994). That said, no type of polling is perfect, and there is no better after-the-fact measure of public opinion available. The most comprehensive post-election poll this year was the bipartisan Democracy Corps/Resurgent Republic survey (DC/RR) (Democracy Corps/Resurgent Republic 2010).

Amongst all voters, 49\% opposed health care reform, while $43 \%$ supported it. For independents, $51 \%$ were opposed, and $39 \%$ were in favor. When intensity was factored in, the gap was much wider. $44 \%$ of all voters strongly opposed the Democrats' health care reform, while only $24 \%$ strongly favored it. Among independents, $43 \%$ were strongly opposed, compared to $18 \%$ in strong support. There was also a stark intensity divide amongst partisans. $87 \%$ of Republicans strongly opposed the Affordable Care Act, while only $49 \%$ of Democrats strongly supported it.

Plenty of other polling data backs up the DC/RR findings. An election night Rasmussen poll, for instance, found that $59 \%$ of voters favored repealing Obamacare, with $49 \%$ strongly in favor of repeal. The clear take-away point here is that the Democrats' healthcare reform was not popular with 2010 voters. Opposition was higher amongst independents - those critical swing voters who often determine election outcomes - than it was with the full electorate, and opponents of the Affordable Care Act felt more strongly than did supporters.

The attitudes of independents merit special attention this year. In 2006, the last midterm election, one in which Democrats gained majorities on Capitol Hill amidst an unpopular war in Iraq, Democrats took $57 \%$ of independent votes. Two years later, with Obama heading the ticket, $51 \%$ of independents cast Democratic ballots. But this year, only $38 \%$ did-a drop of $13 \%$ from twenty-four months ago and $19 \%$ from 2006. For those independents voting Republican, 62\% reported that their ballot represented a vote against Obama and the Democratic agenda, while only $30 \%$ said their vote was cast in support of the Republican Party. When 
asked whether government should be doing more or less, $60 \%$ of independents said less (52\% strongly), while only $34 \%$ said more (27\% strongly). In sum, independents turned dramatically against the Democrats and their agenda this fall.

But did all these attitudes toward the Affordable Care Act and the Democrats actually matter? In other words, how much did Democratic support for healthcare reform contribute to the party's defeat? Given data limitations, these questions are difficult to answer with precision. However, rough and general estimates are possible, and it is clear that voting for healthcare reform hurt incumbent Democrats. Political scientists Seth Masket and Steven Greene (2010) and Eric McGhee and John Sides (2010) modeled the extent to which votes for Obamacare hurt these incumbents. Masket and Greene (2010) found that Democratic House members who voted for the Affordable Care Act performed $5.2 \%$ worse in the election than those who voted against it. McGhee and Sides (2010), meanwhile, found a 4.5\% loss of support for those Democratic incumbents supporting healthcare reform. ${ }^{1}$

Anything that can swing an election by $5.2 \%$ or $4.5 \%$ is a major influence. In 2010, there were eight House Democrats who voted for the Affordable Care Act and lost their seats by less than 5.2\%, while five voted against it and held onto their seats by less than that margin. Other factors were certainly at work, but it seems clear that some Democrats lost their seats in Congress because of their vote on health care reform.

\section{Conclusion}

In January of 2010, when it had become clear that public opinion was not supportive of the Patient Protection and Affordable Care Act, President Obama said that he would "rather be a really good one-term president than a mediocre two-term president." Just one year before, he had taken the oath of office amidst expectations that he was ushering in a realignment that would transform American politics for a generation. Now, one year later, his party has suffered an historic "shellacking," and Washington's chattering classes are debating whether he should even seek a second term.

While it is impossible to know with certainty how much of an influence the healthcare vote had in the election compared to other issues and the standard long-term factors that behavioral political scientists emphasize, the best evidence suggests that Democrats paid a price for passing their healthcare bill. It is disappointing for Democrats that the American public has-at least so far-failed to embrace this historic and critical step on the road toward a nationalized,

1 McGhee and Sides (2010) also examined other controversial votes, finding TARP to be insignificant and the stimulus and cap and trade to have produced $2.8 \%$ and $2.1 \%$ vote losses, respectively. 
universal healthcare system. Meanwhile, many Republicans see the election as a mandate to repeal the law. With Harry Reid running the Senate and Obama in the White House, that is not going to happen anytime soon, but the GOP sees the 2010 midterms as the first step toward reclaiming those perches, too.

Yet, despite the epic electoral defeat, one has to think that Democratic Party luminaries of the past like Harry Truman, John Kennedy, and Lyndon Johnson might be smiling. At some point in a representative, liberal democracy, policy achievements ought to be more important than partisan control of Capitol Hill and the White House. In this era of close partisan competition with frequent changes in control of the House and Senate, some Democrats and liberals probably feel that trading away the House of Representatives for a policy achievement that has eluded generations before them is a price worth paying. And with time, the American public may yet come to embrace the Affordable Care Act as they have other key elements of the welfare state.

Meanwhile, this latest instance of health care reform once again highlights the fragility of partisan regimes. The quadrennial media hype over whether we are witnessing a once-in-a-generation realignment is both silly and an impediment to presidential leadership. Realignment theory, as popularly understood, offers a utopian vision that does not accurately reflect the constant struggles, divisiveness, frustrations, and failures that characterized the administrations of our "great" presidents who presided over realigning moments. The American political system is not designed to produce the uniformity and cohesion that realignment theory too often imposes. Our politics, more accurately depicted, varies by degree of partisan and ideological polarization, not by periods of unity and periods of upheaval.

Talk of realignment might be fine if it was limited to a consideration of a given election's relative importance in the scope of American political history. However, at this point, enough of the political science theory has seeped into popular discourse. Commentators know enough to know what we talk about when we talk about realignment: the heavy hitters of American political history-the Jeffersons and Jacksons, the Lincolns and the Roosevelts. As such, these are the standards for "greatness."

Yet too often, our perceptions of these presidencies and the eras they are said to have ushered in have become distorted. Expectations that our presidents and their parties will live up to these rose-tinted and skewed images of prior golden eras are bound to lead to disappointment. Other factors aside, part of the reason Obama has failed to live up to these expectations is because not even Lincoln or Roosevelt lived up to them. 


\section{References}

Berelson, Bernard R., Paul F. Lazarsfeld, and William N. McPhee. 1954. Voting: A Study of Opinion Formation in a Presidential Campaign. Chicago: University of Chicago Press.

Berkowitz, Edward D. 2010. The Scenic Road to Nowhere: Reflections on the History of National Health Insurance in the United States. The Forum 8 (1), Article 1.

Bernstein, Jonathan. 2010. Proof that Health Care Sunk the Dems? Nope. The New Republic. 11 Nov. 2010. http://www.tnr.com/blog/jonathancohn/79119/proof-health-care-sunk-the-dems-nope. Last accessed 13 Dec. 2010.

Blumenthal, David and James A. Morone. 2009. The Heart of Power: Health and Politics in the Oval Office. Berkeley: University of California Press.

Burnham, Walter Dean. 1970. Critical Elections and the Mainsprings of American Politics. New York: Norton.

Campbell, Angus, Philip E. Converse, Warren E. Miller, and Donald E. Stokes. 1960. The American Voter. New York: Wiley.

Cost, Jay. 2010. Health Care Reform Has Endangered the Democratic Majority. Real Clear Politics. www.realclearpolitics.com/horseraceblog/2010/08 /health_care_reform_has_endange_1.html. Last accessed 13 Dec. 2010.

Davis, Lanny J. 2008. The Obama Realignment. The Wall Street Journal. 6 Nov., A19.

Democracy Corps/Resurgent Republic: First Time Bi-Partisan Post-Election Survery. 2010. http://www.democracycorps.com/wp-content/files/ DCorp-RR-Post-election-11092010.FINAL_.pdf. Last accessed 14 Dec. 2010.

Fiorina, Morris P. 1981. Retrospective Voting in American National Elections (New Haven: Yale University Press). 
Galston, William. 2010. Proof that Obamacare sunk the Democrats-Even Though it Saved Their Souls. The New Republic. 11 Nov. http://www.tnr.com/blog/william-galston/79072/proof-obamacare-sunkthe-democrats-even-though-it-saved-their-souls. Last accessed 13 Dec. 2010.

Green, Joshua. 2007. The Rove Presidency. The Atlantic. Sept. http://www.theatlantic.com/magazine/archive/2007/09/the-rovepresidency/6132/. Last accessed 13 Dec. 2010.

Hacker, Jacob. 1997. The Road to Nowhere: The Genesis of President Clinton's Plan for Health Security. Princeton: Princeton University Press.

Hirshfield, Daniel. 1970. The Lost Reform: The Campaign for Compulsory Health Insurance in the United State from 1932 to 1943. Cambridge: Harvard University Press.

Jacobson, Gary C. 1997. The Politics of Congressional Elections, $4^{\text {th }}$ ed. Boston: Longman.

Judis, John B. 2008. America the Liberal: The Democracy Majority: It Emerged! The New Republic. 19 Nov. 2008. http://www.tnr.com/article/america-theliberal?id=c261828d-7387-4af8-9ee7-8b2922ea6df0. Last accessed 11 Dec. 2010.

Kaiser Health Tracking Poll. 2010. http://www.kff.org/kaiserpolls/8120.cfm. Nov. 2010. Last accessed 14 Dec. 2010.

Key, V.O. 1955. A Theory of Critical Elections. Journal of Politics 17 (1955), 318.

Marmor, Theodore. 1973. The Politics of Medicare. Chicago: Aldine Press.

Masket, Seth and Steven Greene. 2010. The Most Damaging Roll Call Vote. Enik Rising. 5 Nov. http://enikrising.blogspot.com/2010/11/most-damagingroll-call-vote.html. Last accessed 14 Dec. 2010.

Mayhew, David R. 2002. Electoral Realignments: A Critique of an American Genre. New Haven: Yale University Press. 
McGhee, Eric and John Sides. 2010. Which Roll Call Votes Hurt the Democrats? The Monkey Cage. 9 Nov. http://www.themonkeycage.org/2010/11/. Last accessed 14 Dec. 2010.

Oberlander, Jonathan. 2003. The Political Life of Medicare. Chicago: University of Chicago Press.

Olson, Laura Katz. 2010. The Politics of Medicaid. New York: Columbia University Press.

Rahn, Wendy, Jon Krosnick, and Marijke Breuning. 1994. Rationalization and Derivation Processes in Survey Studies of Political Candidate Evaluation. American Journal of Political Science 38: 582-600.

Real Clear Politics. 2010a. Obama and Democrats' Health Care Plan Polling Data. http://www.realclearpolitics.com/epolls/other/obama_and_democrat s_health_care_plan-1130.html\#polls. Last accessed 13 Dec. 2010. -. 2010b. Generic Congressional Vote. http://www.realclearpolitics.com/ epolls/other/generic_congressional_vote-901.html. Last accessed 13 Dec. 2010.

---------. 2010c. President Obama Job Approval. http://www.realclearpolitics.com /epolls/other/president_obama_job_approval-1044.html. Last accessed 13 Dec. 2010.

Saldin, Robert P. 2008. Foreign Affairs and the 2008 Election. The Forum 6 (4), Article 5.

--------. 2010. World War I and the "System of 1896." The Journal of Politics 72 (3), 825-36.

---------. 2011. War, the American State, and Politics since 1898. New York: Cambridge University Press.

Schattschneider, E.E. 1960. The Semisovereign People: A Realist's View of Democracy in America. New York: Holt, Rinehart, and Winston.

Shafer, Byron E. (ed.). 1991. The End of Realignment? Interpreting American Electoral Eras. Madison: University of Wisconsin Press. 
Starr, Paul. 1982. The Social Transformation of American Medicine. New York: Basic Books.

Sundquist, James. L. 1983. The Dynamics of the Party System: Alignment and Realignment of Political Parties in the United States. Washington, D.C.: Brookings Institution. 